\title{
Rare case of symptomatic adrenal myelolipoma
}

\author{
Anna Pokrovskaya, Aida Tarzimanova, Maria Vetluzhskaya, Valery Podzolkov
}

Department of Faculty Therapy \# 2, I M Sechenov First Moscow State Medical University (Sechenov University), Moscow, Russian Federation

\section{Correspondence to}

Dr Maria Vetluzhskaya; maria.vetluzhskaya@gmail.com

Accepted 28 September 2021

\section{DESCRIPTION}

A 36-year-old man presented to the clinic with frequent headaches and a brief episode of fainting. He said that he had experienced headache for a few months and occasionally had found his arterial pressure to be elevated at $180 / 120 \mathrm{~mm} \mathrm{Hg}$. He sometimes felt feverish and shivering all over, which was accompanied by sweating and then strong fatigue. The patient did not experience any abdominal or lower back pain. He denied having any other medical conditions. He stated that he had lost $40 \mathrm{~kg}$ over the past year without taking any medications. This weight loss reduced dyspnoea on exertion that had interfered with the patient's daily activity. His family history and social status were unremarkable. On physical examination, his height was $177 \mathrm{~cm}$; weight $110 \mathrm{~kg}$; body mass index (BMI) $35.1 \mathrm{~kg} / \mathrm{m}^{2}$. Vital signs were blood pressure (BP) 160/115 mm Hg, pulse $90 \mathrm{bpm}$, respiratory rate 18 breaths per minute. The abdomen was asymmetrically enlarged on its right side, with a painless and immobile mass of dense elastic consistency palpable in his right upper quadrant. The complete blood count (CBC) revealed decreased haemoglobin $(119 \mathrm{~g} / \mathrm{L}$; reference ranges $135-165 \mathrm{~g} / \mathrm{L}$ ) and low red blood cells count $\left(3.7 \times 10^{12} / \mathrm{L}\right.$; reference ranges $\left.4.2-5.5 \times 10^{12}\right)$ L). Basic metabolic panel (BMP) revealed decreased level of total protein $(59.6 \mathrm{~g} / \mathrm{L}$; reference ranges $66-83$ $\mathrm{g} / \mathrm{L}$ ) and slight hyperglycaemia up to $6.5 \mathrm{mmol} / \mathrm{L}$ (reference ranges 3.9-5.8 $\mathrm{mmol} / \mathrm{L}$ ). Other parameters of BMP as well as liver function test, coagulation panel and urinalysis were normal. Changes in $\mathrm{CBC}$ and BMP were interpreted as a result of continuous unbalanced diet in order to lose weight. The patient's glomerular filtration rate was $110 \mathrm{~mL} / \mathrm{min} / 1.73 \mathrm{~m}^{2}$ established

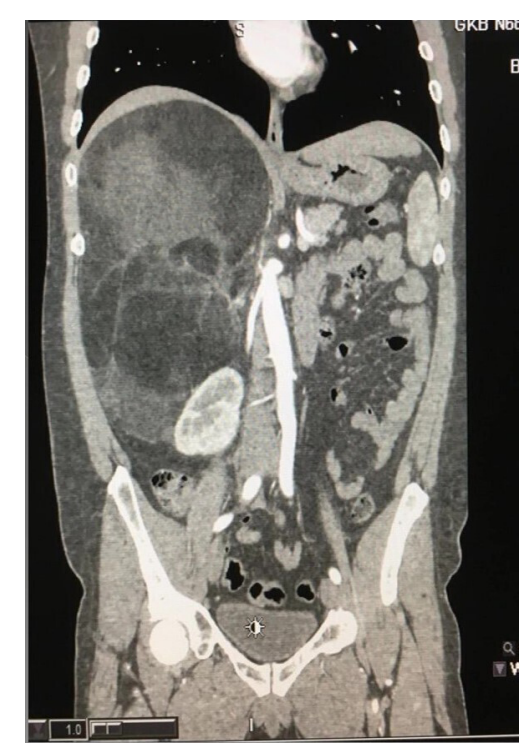

Figure 1 Abdominal CT with a mass near the right adrenal gland.

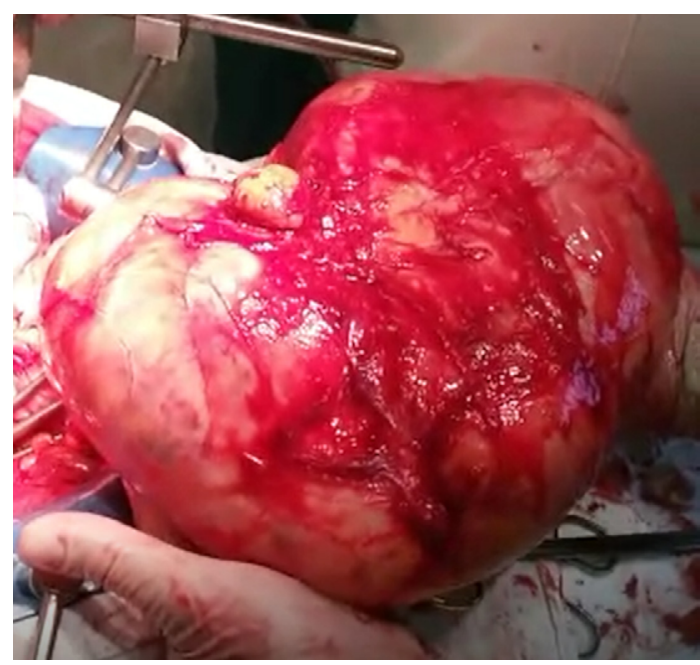

Figure 2 Laparotomic excision of the myelolipoma.

by CKD-EPI equation. Ultrasound of kidneys and adrenal glands revealed a mass on the right adrenal gland. No kidney disease was confirmed. Abdominal CT found a voluminous mass of adipose density in the right-hand mesogastrium, $233 \times 181 \times 257 \mathrm{~mm}$ in size, thinly encapsulated and closely adjacent to the right adrenal gland; the latter's dimensions were unaltered (figure 1). The giant size of the tumour and its clinical manifestation with arterial hypertension were the indications for surgery. The patient was laparotomised and the tumour of his right adrenal removed (video 1 , figures 2 and 3). Histopathological examination revealed myelolipoma. The postoperative period was unremarkable. On a follow-up visit 2 months later, the patient had no complaints and reported no shivering, tachycardia or sweating episodes. His BP achieved normal values. His BMI was $30.2 \mathrm{~kg} / \mathrm{m}^{2}$.

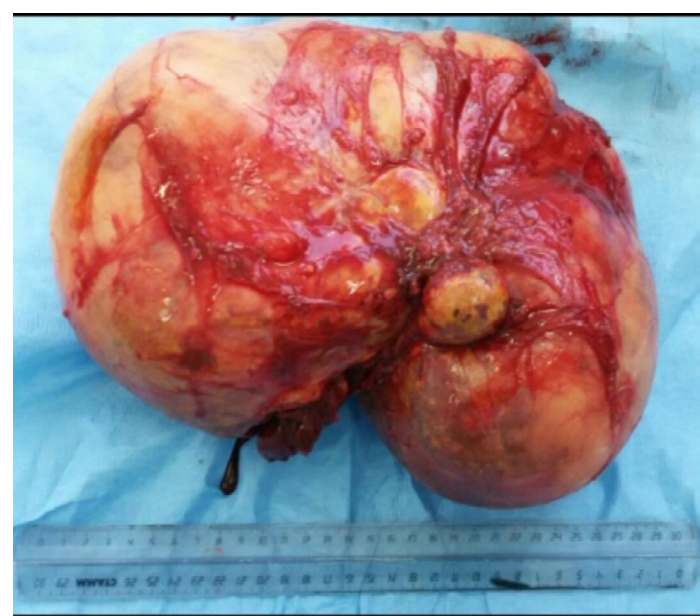

Figure 3 Adrenal myelolipoma. 


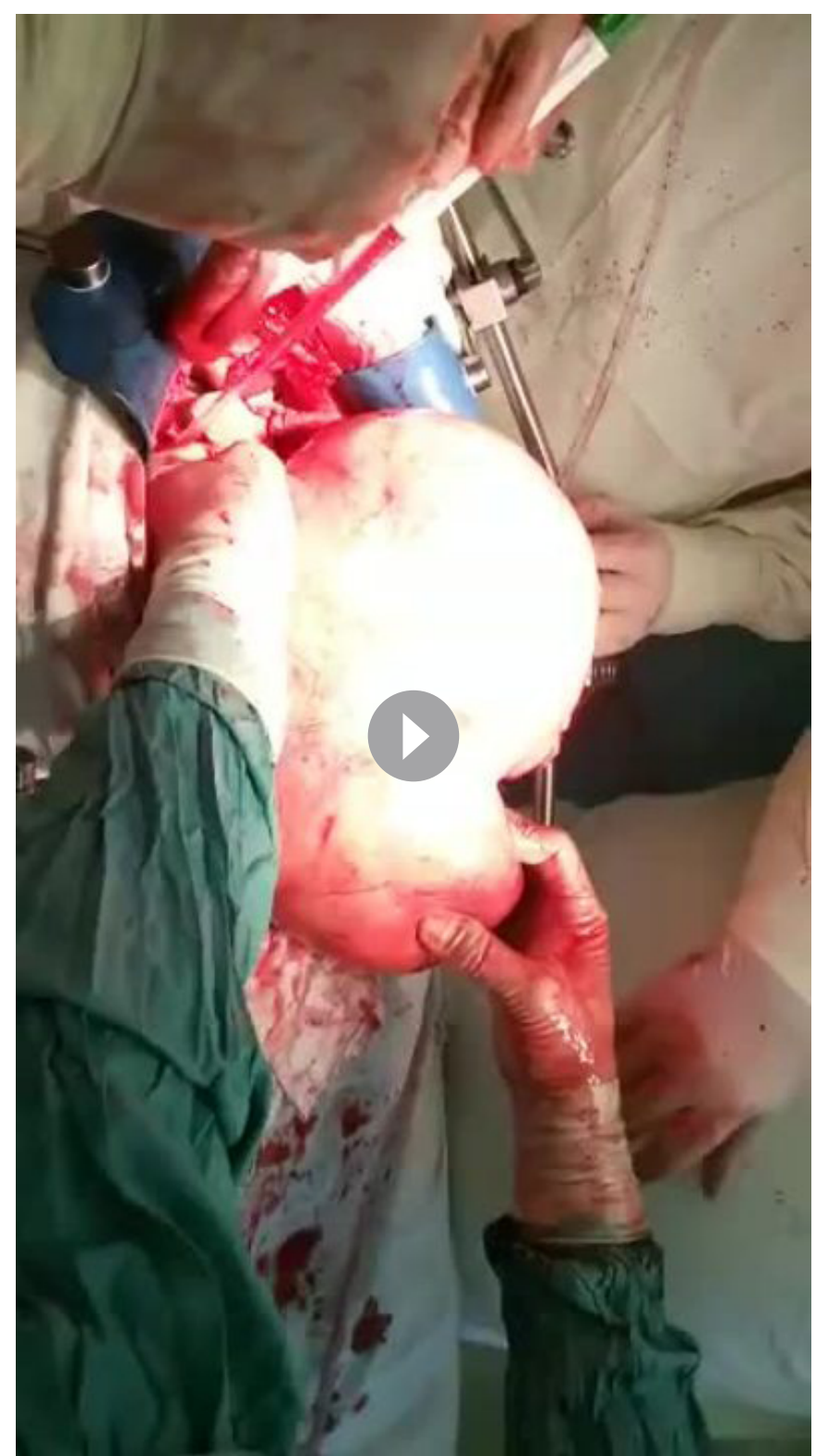

Video 1 Surgical excision of myelolipoma

Adrenal myelolipoma is a benign adrenal neoplasm consisting of lipoid and myeloid tissue. Myelolipoma prevalence in general population is $0.2 \%$, according to autopsy studies. ${ }^{1}$ Myelolipomas occur in $6 \%-16 \%$ of the primary adrenal incidentaloma cases and are the second most common cause following adrenocortical adenomas. The detection of myelolipomas has been increased in the recent years due to wider accessibility of CT and MRI. ${ }^{2}$ The patients' average age for the diagnosis is about 51 years. ${ }^{3}$ According to literature, this tumour is more frequent in women and is found twice as often in the right adrenal gland as in the left one. ${ }^{4}$ Most myelolipomas are asymptomatic and found incidentally during tomography given for another reason. The most frequent symptoms are abdominal pain (22.5\%), flank pain (13.9\%), or abdominal or flank discomfort. ${ }^{23}$ Endocrine dysfunction occurs rarely, in some $7 \%$ of the cases, manifesting itself as overproduction of various hormones: glucocorticosteroids, catecholamines, aldosterone and/or sex hormones. The pathogenesis remains obscure, but there is a theory that a hormonal hypersecretion results from mechanical irritation of the adrenal by myelolipoma. In this case, the endocrine dysfunction should

\section{Patient's perspective}

I knew that a headache could be a possible symptom of high blood pressure and that blood pressure should not be higher than $140 / 90 \mathrm{~mm} \mathrm{Hg}$, so I went to see my doctor immediately after I found I had arterial hypertension. I am happy to have had the root cause of my illness surgically eliminated.

\section{Learning points}

Myelolipoma is a benign tumour of the adrenal gland, usually detected incidentally during imaging examinations.

- In rare cases, giant myelolipoma may cause arterial hypertension due to the compression of the adrenal tissue and hyperincretion of cortisol. Surgical removal of a giant myelolipoma may help to achieve normal endocrine status and BP levels.

- Examinations of young patients presenting with arterial hypertension and obesity should include imaging of their adrenal glands.

resolve after surgical excision. ${ }^{4}$ Rarely myelolipomas may be complicated by acute bleeding with haemorrhagic shock developing. ${ }^{1}$ The risk of spontaneous rupture is higher in tumours larger than $60 \mathrm{~mm}^{4}$ If the diagnosis of adrenal myelolipoma is confirmed, the size of tumour does not exceed $40 \mathrm{~mm}$ and there are no endocrine dysfunction or associated symptoms, surgical treatment is not indicated. ${ }^{35}$ In such cases, conservative management can be applied with a routine imaging follow-up to monitor the tumour size. Surgery is indicated for such complications as bleeding, tumour necrosis and in tumours more than $60 \mathrm{~mm}$ in size as a large size of myelolipoma increases the risk of these complications and can also result in surrounding tissue compression symptoms and signs including arterial hypertension. ${ }^{5}$

In this study, we present a case of a giant myelolipoma of the right adrenal gland that remained asymptomatic for a long time. The myelolipoma manifested with arterial hypertension and associated symptoms probably due to the compression of the right adrenal gland tissue and hyperincretion of cortisol since all symptoms and signs were resolved after surgical removal of the tumour and the patient's BP remained within target values. The clinician should be aware that high BP may be caused by adrenal myelolipoma, commonly considered to be endocrine-inactive or non-functional neoplasm.

Twitter Anna Pokrovskaya @Anna Pokrovskaya

Acknowledgements We would like to acknowledge all the surgical team of the City Clinical Hospital named by VP Demichov, Department of Health, Moscow, RF, especially surgeon Kupriyanov EY and Head of Surgical Department \#1 Soshkin NN. We would also like to acknowledge our reviewers and all people who have contributed significantly in this case editing and publishing.

Contributors MV, AP, AT and VP participated in data collection, interpretation and article concept planning. AP participated in the writing of the manuscript; VP edited the manuscript. All authors have read the final version of the manuscript and agree for publication.

Funding The authors have not declared a specific grant for this research from any funding agency in the public, commercial or not-for-profit sectors.

Competing interests None declared.

Patient consent for publication Consent obtained directly from patient(s)

Provenance and peer review Not commissioned; externally peer reviewed. 


\section{REFERENCES}

1 Liu H-P, Chang W-Y, Chien S-T, et al. Intra-Abdominal bleeding with hemorrhagic shock: a case of adrenal myelolipoma and review of literature. BMC Surg 2017; 17:74.

2 Bokhari MR, Zulfiqar H, Garla VV. Adrenal Myelolipoma. In: StatPearls. Treasure Island (FL): StatPearls Publishing, 2021.
3 Decmann Ábel, Perge P, Tóth M, et al. Adrenal myelolipoma: a comprehensive review. Endocrine 2018;59:7-15.

4 Lam AK-Y. Lipomatous tumours in adrenal gland: who updates and clinical implications. Endocr Relat Cancer 2017;24:R65-79.

5 Azizan N, Myint O, Wynn AA, et al. A clinically silent tumour of adrenal myelolipoma: a case report. Int J Surg Case Rep 2020;72:63-5.

Copyright 2021 BMJ Publishing Group. All rights reserved. For permission to reuse any of this content visit

https://www.bmj.com/company/products-services/rights-and-licensing/permissions/

BMJ Case Report Fellows may re-use this article for personal use and teaching without any further permission.

Become a Fellow of BMJ Case Reports today and you can:

- Submit as many cases as you like

- Enjoy fast sympathetic peer review and rapid publication of accepted articles

- Access all the published articles

Re-use any of the published material for personal use and teaching without further permission

\section{Customer Service}

If you have any further queries about your subscription, please contact our customer services team on +44 (0) 2071111105 or via email at support@bmj.com.

Visit casereports.bmj.com for more articles like this and to become a Fellow 